\title{
How migratory thrushes conquered northern North America: A comparative phylogeography approach
}

Five species of migratory thrushes (Turdidae) occupy a transcontinental distribution across northern North America. They have largely overlapping breeding ranges, relatively similar ecological niches, and mutualistic relationships with northern woodland communities as insectivores and seed-dispersing frugivores. As an assemblage of ecologically similar species, and given other vertebrate studies, we predicted a shared pattern of genetic divergence among these species between their eastern and western populations, and also that the timing of the coalescent events might be similar and coincident with historical glacial events. To determine how these five lineages effectively established transcontinental distributions, we used mitochondrial cytochrome b sequences to assess genetic structure and lineage coalescence from populations on each side of the continent. Two general patterns occur. Hermit and Swainson's thrushes (Catharus guttatus and C. ustulatus) have relatively deep divergences between eastern and western phylogroups, probably reflecting shared historic vicariance. The Veery (C. fuscescens), Gray-cheeked Thrush (C. minimus), and American Robin (Turdus migratorius) have relatively shallow divergences between eastern and western populations. However, coalescent and approximate Bayesian computational analyses indicated that among all species as many as five transcontinental divergence events occurred. Divergence within both Hermit and Swainson's thrushes resembled the divergence between Gray-cheeked Thrushes and Veeries and probably occurred during a similar time period. Despite these species' ecological similarities, the assemblage exhibits heterogeneity at the species level in how they came to occupy transcontinental northern North America but two general continental patterns at an amongspecies organizational level, likely related to lineage age. 
2 Carrie M. Topp ${ }^{1}$, Christin L. PruetT ${ }^{2}$, Kevin G. McCracken ${ }^{1}$, And KeVIn WinkeR ${ }^{1,3}$ 3

$4 \quad{ }^{1}$ University of Alaska Museum and Institute of Arctic Biology, University of Alaska

5 Fairbanks, Fairbanks, Alaska 99775, USA.

$6 \quad{ }^{2}$ Florida Institute of Technology, Department of Biological Sciences, Melbourne, Florida

7 32901, USA.

$8 \quad{ }^{3}$ E-mail: kevin.winker@alaska.edu

Corresponding Author: KEVIN WINKER

University of Alaska Museum, 907 Yukon Drive, Fairbanks, Alaska 99775, USA,

E-mail: kevin.winker@alaska.edu, Phone: (907) 474-7027, Fax: (907) 474-5469 


\section{INTRODUCTION}

IT HAS BEEN suggested that the North American avifauna is a composite of species with

10 different colonization and isolation histories because multiple phylogeographic patterns are seen

11 in many species that are presently co-distributed (Zink 1996, Avise 2000, Carstens et al. 2005).

12 However, closely related and ecologically similar species may be more tightly associated with

13 each other over time compared to groups of co-occurring species that are ecologically varied

14 (Richman \& Price 1992, Webb 2000, Webb et al. 2002, Lovette \& Hochachka 2006).

In this study we examined five migratory thrush species with breeding ranges across northern

16 North America: Hermit Thrush (Catharus guttatus), Swainson's Thrush (C. ustulatus), Gray-

17 cheeked Thrush (C. minimus), Veery (C. fuscescens), and American Robin (Turdus migratorius).

18 These species are relatively common members of northern woodland bird assemblages, and their

19 breeding ranges are mostly or partly overlapping (Fig. 1; Jones \& Donovan 1996, AOU 1998,

20 Sallabanks \& James 1999, Mack \& Yong 2000, Lowther et al. 2001, Maskoff 2005). They are

21 each others' closest relatives in these communities, excluding Bicknell's Thrush (C. bicknelli),

22 which we did not include because it has a small breeding range only on the eastern side of the

23 continent (AOU 1998, Rimmer et al. 2001, Klicka, Voelker, \& Spellman 2004, Winker \& Pruett

24 2006, Voelker, Bowie, \& Klicka 2013). We also excluded two other thrush species whose ranges

25 do not span the continent: Varied Thrush (Zoothera naevia) and Wood Thrush (Hylocichla

26 mustelina; AOU 1998).

27 The five species chosen for this study occur in a variety of woodlands and occupy — on a

28 community scale - similar niches as forest and woodland mutualists (all of them are insectivores,

29 seasonal frugivores, and seed dispersers); they are likely to be each others' closest competitors in

30 these communities (Bent 1949, Jones \& Donovan 1996, Sallabanks \& James 1999, Mack \& Yong

31 2000, Lowther et al. 2001, Maskoff 2005). Population genetics and phylogeography at the

32 continental scale, paired with the known ecology of these species, can inform us about how these 
33 five similar but independent lineages successfully came to occupy transcontinental ranges across

34 northern North America to become integral members of forest communities. This combination of

35 ecology and genetics is part of a growing examination of the interaction between evolutionary

36 history and the ecological processes determining the makeup of assemblages and communities

37 (Ricklefs 1987, 2007, Johnson \& Stinchcombe 2007, Andrew et al. 2013).

38 Because of the close evolutionary history, ecological similarity, and transcontinental

39 distribution of these five species, we hypothesized that they might share similar historical

40 patterns across northern North America. Many transcontinental vertebrate species and species

41 complexes have a pattern of mtDNA genetic divergence across North America showing a split

42 between a western coastal lineage and an eastern lineage (e.g., Milot, Gibbs, \& Hobson 2000,

43 Omland et al. 2000, Arbogast \& Kenagy 2001, Kimura et al. 2002, Ruegg \& Smith 2002, Peters,

44 Gretes, \& Omland 2005, Milá, Smith \& Wayne 2007). This pattern has been largely regarded as a

45 result of Pleistocene glacial cycles and the accompanying climatic and ecological changes (Pielou

46 1991, Arbogast \& Kenagy 2001, Weir \& Schluter 2004). Thus, we refine our hypothesis of shared

47 histories to include an expectation of a clear genetic break between eastern and western

48 phylogroups.

49 We asked three questions: (1) Is there a pattern of genetic divergence between eastern and

50 western populations, as suggested by other vertebrate studies? (2) Do coalescent events, such as

51 lineage divergence, between eastern and western populations occur at similar times, and do these

52 match historic glacial events? (3) Did these five ecologically similar, co-distributed thrush

53 species come to occupy their ranges across northern North America in the same way, showing

54 similar patterns of expansion?

55 Methods

56 Sampling and mtDNA sequencing.-The five migratory North American thrush species in this 57 study represent all of the thrushes that are distributed across North America at higher latitudes, 
58 where they have mostly or partly overlapping breeding ranges (Fig. 1). We sampled thrush

59 assemblages on each side of the continent to understand continental-scale patterns; finding finer-

60 scale phenomena such as the location and shape of contact zones or clines between possible

61 eastern versus western clades was not one of our goals, and we do not ask how these lineages

62 came to exist on the continent itself (for which see Outlaw et al. 2003, Voelker et al. 2007, 2009).

63 For comparisons across the continent of North America, we used two main sample regions along

64 the northern coasts: Eastern = Nova Scotia $(\mathrm{NvSc})$ and Newfoundland (Newf), Canada; and

65 Western = interior Alaska (AK); southeast Alaska (SE AK); Hyder, Alaska (Hyder); Queen

66 Charlotte Islands, Canada (QCI); and Washington state (WA; Fig. 1). Specimen voucher numbers

67 and GenBank accession numbers are listed in Appendix 1.

68 Total genomic DNA was extracted from muscle tissue following Glenn (1997) or DNeasy

69 DNA purification kit protocols (Qiagen, Valencia, California). Most or all of the cytochrome $b$

70 gene was amplified using the reverse primer H16064 (Harshman 1996) and the following forward

71 primers: L14703 (C. Huddleston pers. comm.) for Hermit Thrush and Gray-cheeked Thrush

72 (1,143 bp); L14841 (Kocher et al. 1989) for Veery (1,045 bp); and L1650ND5 (Winker \& Pruett

73 2006) for Swainson's Thrush (1,094 bp) and American Robin (1,143 bp). All amplifications were

74 performed using standard polymerase chain reaction (PCR) protocols (Hillis, Moritz, \& Mable

75 1996) and cycle sequenced using Big Dye Terminator 3.1 and sequenced in both directions on an

76 ABI 373, 3100, or 3130xl automated sequencer (Applied Biosystems Inc., Foster City, CA). We

77 sequenced the mtDNA gene cytochrome $b$ because it is a well-studied gene with a fairly constant

78 rate of evolution and has proven useful in many phylogeographic and population genetic studies

79 (Moore \& DeFilippis 1997, Avise 2000).

80 Summary statistics and haplotype networks. - Mitochondrial sequence data were edited and

81 checked for stop codons indicative of nonfunctional nuclear copies using Sequencher 4.7 (Gene

82 Codes Corp., Ann Arbor, MI). Using DnaSP version 4.20.2 (www.ub.es/dnasp/; Rozas et al. 
83 2003), sequences were examined for variable base pairs, haplotype variation $(\mathrm{H})$, segregating

84 sites (S), haplotype diversity (h), and nucleotide diversity per site $(\pi)$. Statistical parsimony

85 networks were made with TCS 1.21 (http://darwin.uvigo.es/software/tcs/html; Clement, Posada,

86 \& Crandall 2000) to visualize haplotype relationships.

87 Phylogenetic analyses. - Based on preliminary analyses, we noted that a pattern of deep

88 divergence within Hermit and Swainson's thrushes appeared to be similar to that occurring

89 between the Gray-cheeked Thrush and Veery. Therefore, separate from our within-species

90 analyses of eastern and western populations, we also conducted analyses to understand this

91 possibly similar historic divergence event between species.

92 The nucleotide substitution model for each species was selected using PAUP* $4.0 \mathrm{~b} 10$

93 (Swofford 2001) and the Akaike Information Criterion (AIC) for model selection as implemented

94 in Modeltest 3.6 (http://darwin.uvigo.es/ software/modeltest.html; Posada \& Crandall 1998,

95 Posada \& Buckley 2004). The best-fit maximum likelihood models were used in reconstructing

96 phylogenetic trees for each species: HKY for American Robin and Gray-cheeked Thrush; TrN for

97 the Veery and the combination of Gray-cheeked Thrush and Veery; TrN+I for the Hermit Thrush;

98 and K81uf + I for Swainson's Thrush.

99 Phylogenetic trees for each species were reconstructed in MrBayes 3.1.2

100 (http://mrbayes.csit.fsu.edu; Huelsenbeck \& Ronquist 2001, Ronquist \& Huelsenbeck 2003,

101 Altekar et al. 2004) and rooted with closely related outgroup taxa. Outgroup sequences were

102 acquired from GenBank or from UA Museum specimens (Appendix 2). Four independent runs

103 starting from random trees were used for each species to ensure that the Markov chain converged

104 on the optimal likelihood value. Trees were sampled every 10,000 generations, and the analyses

105 were run for 8 million generations. All trees sampled before the Markov chain plateaued were

106 discarded (the burnin), and remaining trees were used to approximate posterior probabilities for 
107 each phylogeny (Huelsenbeck \& Ronquist 2001). A burnin of 100,000 generations was sufficient

108 in all species. The remaining 791 trees were then imported into PAUP* 4.0b10 (Swofford 2001),

109 where $50 \%$ majority rule consensus trees were generated with the posterior probabilities of each

110 clade recorded as the percentage of that clade occurring among all the sampled trees

111 (Huelsenbeck \& Ronquist 2001).

112 Historic population changes. - Changes in the site-frequency pattern of DNA polymorphisms

113 that may be associated with past changes in population size were assessed using $\mathrm{R}_{2}$ and Fu's $F_{s}$

114 statistics, as implemented in DnaSP 4.20.2 (Rozas et al. 2003, Romis-Onsins \& Rozas 2002). We

115 chose $\mathrm{R}_{2}$ and Fu's $F_{s}$ because they are more powerful tests than statistics based on mismatch

116 distributions, and $\mathrm{R}_{2}$ provides superior estimates when sample sizes are small (Romis-Onsins \&

117 Rozas 2002). The probability of our results under a model of constant population size was

118 determined in DnaSP version 4.20.2 (Rozas et al. 2003) with 1,000 coalescent simulations based

119 on observed $\theta\left(2 N_{e} \mu\right)$ per gene, where $N_{e}$ is the effective population size and $\mu$ is the mutation rate

120 per sequence per generation.

121 Coalescent analyses.-To estimate divergence times we used the coalescent program

122 Isolation with Migration (IM version 10.10.07; http://lifesci.rutgers.edu/

$123 \sim$ heylab/HeylabSoftware.htm; Hey \& Nielsen 2004), which uses a Markov chain Monte Carlo

124 (MCMC) approach. IM incorporates effective population sizes and migration rates while

125 simultaneously estimating divergence time. Using IM, we estimated the time of divergence $(t)$

126 between eastern and western populations and the time to most recent common ancestor

127 (TMRCA). These parameters were scaled to the neutral mutation rate, making it possible to

128 directly compare results between species. We compared $t$-values among the five species to

129 examine coalescent patterns between eastern and western populations. To determine whether

130 divergence dates within Hermit and Swainson's thrushes were similar to the divergence between

131 the Gray-cheeked Thrush and the Veery we compared estimates of TMRCA. 
132 To make a rough estimate of the timing of divergences, we converted $t$-values and TMRCA-

133 values from IM to time in years using a generation time of one year and the estimated mutation

134 rate of about $2 \%$ sequence divergence per million years for mtDNA in birds (Hey \& Nielsen

135 2004, Lovette 2004, Weir \& Schluter 2008). This estimate is imprecise, but it enables us to

136 roughly date these divergences (Weir \& Schluter 2008, Ho et al. 2005, 2011, Pereira \& Baker

137 2006).

138 At least three runs were performed in IM for each species: an initial run to estimate

139 appropriate priors and then two additional independent runs with identical conditions but

140 different random number seeds to confirm convergence. The runs with the highest effective

141 samples sizes (ESS) were chosen to report results.

142 To set an upper prior for $t$, we assumed that the time since divergence could not be older than

143 TMRCA, and we used the upper 95\% credible interval value from preliminary runs to set the

144 upper bound for $t$ in each species (Peters et al. 2007). We ran IM for a different number of total

145 steps for each dataset based on preliminary runs to ensure that the lowest ESS values were at least

146500 (Hey \& Nielson 2004): Hermit and Swainson's thrushes were run with 15,000,000 steps; the

147 Gray-cheeked Thrush, Veery, and American Robin were run using 10,000,000 steps; Gray-

148 cheeked Thrush and Veery combined as one dataset was run for 20,000,000 steps. For all species

149 we used a burnin of $1,000,000$ steps.

150 Testing divergence hypotheses-To test the hypothesis of simultaneous divergence or

151 establishment times across northern North America, we used msBayes

152 (www.msbayes.sourceforge.net/; Hickerson, Stahl, \& Lessios 2006, Hickerson, Stahl, \&

153 Takebayashi 2007). This program uses an approximate Bayesian computational (ABC)

154 framework that tests for simultaneous divergence across multiple co-distributed taxon pairs

155 (taxon pair = taxon with two populations) using a hierarchical model that incorporates intrinsic

156 variation such as ancestral coalescence and among-taxon demographic histories (Hickerson, 
157 Stahl, \& Lessios 2006, Hickerson, Stahl, \& Takebayashi 2007). This method allows for the

158 simultaneous estimation of three hyperparameters that characterize the mean $(\mathrm{E}[\tau])$, variability

$159(\Omega)$, and number of separate divergence events $(\Psi)$ across multiple population pairs. ABC obtains

160 these estimates by simulating data and their summary statistics from the joint prior distribution

161 under a model and then sampling from the resulting joint posterior distribution using probabilities

162 based on the similarity between the summary statistic vector for the observed versus the

163 simulated data (Hickerson, Stahl, \& Lessios 2006, Hickerson, Stahl, \& Takebayashi 2007). These

164 methods are effective even with population sample sizes of five or less (Hickerson, Stahl, \&

165 Takebayashi 2007).

We examined two datasets with msBayes: (1) the five thrush taxa with eastern and western populations to test our main hypothesis; and (2), in a post hoc analysis given the mtDNA results, a three 'taxon' set of Hermit Thrush (E-W) and Swainson's Thrush (E-W) phylogroups and Graycheeked Thrush and Veery combined. The three 'taxon' set was based on the observation that the pattern of deep divergence within Hermit and Swainson's thrushes appeared to be similar to the divergence between the Gray-cheeked Thrush and Veery. This second analysis thus enabled us to test a secondary hypothesis that these three pairs of mtDNA clades might have a similar timing of divergence. The divergent clades within Hermit and Swainson's thrushes did not perfectly match eastern and western sampling locations (e.g., a few western birds had eastern haplotypes), so for this three 'taxon' analysis we used the phylogroups labeled eastern and western, based on sample locations. More details are given in Results.

We ran two million simulations in msBayes using the following starting parameters for the upper and lower bounds of prior distributions: $\theta$ lower $=0.5$ (default), $\theta$ upper $=20.0$ for the fivetaxa dataset, and $\theta$ upper $=5.0$ for the three 'taxon' dataset (based on the highest $\pi_{W}$ from observed summary statistics as recommended by Hickerson, Stahl, \& Lessios 2006), $\tau$ upper $=$ 
10.0 for the five-taxa dataset, and $\tau$ upper $=15.0$ for the three 'taxon' dataset (based on relatively recent divergence in the last 1 or 1.5 million years), migration rate upper $=10.0$ (some migration is possible), recombination rate upper $=0.0$ (mtDNA is unlikely to have recombination in birds), and ancestral population size upper $=0.5$ (default). We report joint posterior estimates based on the summary statistic vector $\mathbf{D}$ that includes 13 summary statistics (see Hickerson, Stahl, \& Lessios 2006) per taxon pair. We sampled the posterior distribution with a tolerance of 0.0005 and 0.00025 , which yielded estimates based on 1000 and 500 draws from the joint posterior distribution, given that there were two million simulated draws from the joint prior. Results are presented using a tolerance of 0.00025 , because this sampling parameter showed better resolution in the posterior probability density graph (peaks were more cleanly shaped), although results were very similar for both tolerance levels.

\section{RESULTS}

Genetic variation.-The five thrush species had varying degrees of intraspecific genetic

168 diversity, with the lowest number of haplotypes being 5 and the highest number 24 (Table 1). For

169 all five species, more than $50 \%$ of the nucleotide substitutions were third position synonymous 170 changes.

171 Two very different broad patterns were observed among species in the statistical

172 parsimony networks (Fig. 2). Hermit and Swainson's thrushes had two deeply divergent lineages 173 separated by 21 and 14 nucleotide differences, respectively; we will hereafter refer to these 174 phylogroups as eastern and western (Fig. 2). The eastern phylogroups are primarily made up of 175 individuals from eastern North America and interior Alaska (the latter has a stronger avifaunal 176 affinity with eastern than western North America in these taxa; Phillips 1991). The western group 177 is primarily made up of individuals from southeast Alaska. Gray-cheeked Thrush, Veery, and 178 American Robin, in contrast, showed no differences greater than two nucleotide substitutions 179 between closest haplotypes (Fig. 2). However, each species had a slightly different pattern of 
relationship between haplotypes sampled from eastern and western locations, and the two species

181 with divergent lineages (Hermit and Swainson's thrushes) had haplotypes from both the eastern

182 and western phylogroups in western populations (Fig. 2). In both species, individuals from

183 Hyder, Alaska possessed haplotypes from both phylogroups, suggesting a zone of contact

184 between eastern and western populations (Fig. 2a and b). The eastern Hermit Thrush phylogroup

185 included one individual from Hyder and all of the Washington, interior Alaska, and eastern

186 individuals, whereas the western phylogroup had the majority of the Hyder and all of the QCI

187 individuals (Fig. 2a). The eastern Swainson's Thrush phylogroup contained five individuals from

188 Hyder and all of the eastern individuals (Nova Scotia and Newfoundland), and the western

189 phylogroup had all the QCI and Washington individuals and the remaining four Hyder birds (Fig.

190 2b).

191 Phylogenetic patterns.-The same two general patterns observed among the five species'

192 haplotype networks (Fig. 2) were also observed in the Bayesian phylogenetic trees: Hermit and

193 Swainson's thrushes had two divergent lineages with high posterior probabilities, and the other

194 species had much less structure (Fig. 2). A Bayesian tree of the relationship between the Gray-

195 cheeked Thrush and the Veery also had high posterior probabilities for nodes associated with the

196 species-level split (Fig. 2f). The Bayesian phylogram of the Gray-cheeked Thrush and Veery

197 combined showed an overall similarity to the within-species divergences observed in Hermit and

198 Swainson's thrushes (Fig. 2f).

Historic population changes.- Significant excess of low frequency polymorphism, potentially associated with deviations from constant population size (a signal of recent rapid population expansion) were detected in: the combined Gray-cheeked Thrush sample locations and also in its samples from western North America, the eastern sampling locations of Swainson's Thrush, and both the eastern and western phylogroups of Hermit and Swainson's thrushes (Table 1). Only the Gray-cheeked Thrush had a significant signal of recent rapid 
population expansion for an entire species (Table 1). Veeries and American Robins did not differ significantly from a model of historic population stability (Table 1). The eastern population of American Robins, all Hermit Thrushes combined, and the western population of Hermit Thrushes had very high probabilities $(P>0.94)$ of observed $\mathrm{R}_{2}$ values under an equilibrium model of historic population stability (Table 1).

Coalescent analyses.-Divergence times inferred using IM were also consistent with phylogenetic results, indicating two main patterns: deeper divergence within Hermit and Swainson's thrushes and between the Gray-cheeked Thrush and the Veery, and shallow divergence within the Gray-cheeked Thrush, Veery, and American Robin. IM analyses showed strongly unimodal posterior distributions for $t$ and TMRCA for all thrushes. Both the Hermit Thrush and American Robin divergences between eastern and western sampling locations had posterior distributions of $t$ with tails that did not approach zero, effectively making the upper $95 \%$ credible intervals infinity; however they also had clearly defined unimodal peaks. In both cases we used the upper 95\% credible interval value estimated for TMRCA to set an upper bound on $t$ because we assumed $t$ could not be greater than TMRCA (Fig. 3). The Hermit Thrush posterior distribution for $t$ peaked over a range similar to other species' eastern-versus-western population $t$-values, and the distribution values that went to infinity were flat but very close to zero (not shown). This result for the Hermit Thrush suggests that the eastern population diverged recently, within the last 100,000 years before present (ybp), from the western population (all individuals sampled from the west of North America regardless of phylogroup). However, given other evidence that might reduce divergence estimates, such as the Hyder-region contact zone and likelihood of gene flow, we cannot rule out the possibility that this divergence occurred much earlier $(\leq 1.5$ million ybp; Table 2, Fig. 3$)$ with subsequent secondary contact between lineages. Credible intervals for TMRCA and $t$ broadly overlapped in the American Robin and Veery. These species also exhibited little genetic structure, and eastern and western individuals shared 
haplotypes, suggesting little or no divergence across the continent (Table 2, Figs. 2 and 3). Graycheeked Thrush populations had a TMRCA date with 95\% credible interval that overlapped the credible intervals of $t$ (Fig. 3), and eastern and western populations did not share haplotypes. This indicates an older divergence event between eastern and western Gray-cheeked Thrushes than in the American Robin or the Veery (Figs. 2 and 3). Hermit and Swainson's thrushes showed deep divergences $(\mathrm{TMRCA}=1.03$ million ybp and 750,000 ybp, respectively) between eastern and western phylogroups, but eastern phylogroup haplotypes were found in eastern and western populations, resulting in a shallow divergence $(t=70,000 \mathrm{ybp}$ and $60,000 \mathrm{ybp}$, respectively) between the two sides of the continent (Table 2, Figs. 2 and 3). These results parallel results from our other analyses for these two species. The TMRCA 95\% credible interval $(490,000-925,000$ ybp) between the Gray-cheeked Thrush and Veery overlapped the TMRCA 95\% credible intervals for divergence between eastern and western phylogroups within the Hermit Thrush (720,000 ybp - 1.5 million ybp) and within Swainson's Thrush (500,000 ybp - 1.14 million ybp), which also parallels our other results (Table 2, Figs. 2 and 3).

Testing divergence hypotheses. - The results from msBayes showed that among the five thrush species there were as many as five different divergence events, while the 'three' taxon dataset of Hermit Thrush, Swainson's Thrush, and Gray-cheeked Thrush and Veery combined indicated a single shared divergence event.

For the five thrush species, the ratio of variance to mean divergence time was $\Omega=2.15$ (95\% quantiles $=0.94-6.56)$, which indicated multiple divergence events as estimated in msBayes $(\Omega=$ 0 is expected for a set of population pairs with one divergence event). The number of divergence times across the five taxon pairs was five on the density graph (Fig. 4), with the highest point twice as high as all other values; however, there was a medium-density flat line across the other values that was slightly higher (around a mode of $\Psi=2.36 ; 95 \%$ quantiles $=1.00-5.00$ ). This 
means that we can reject the hypothesis of one divergence event and that five is most likely, although there is a possibility that anywhere from two to five divergence events occurred. These results thus do not support a similar pattern of transcontinental occupancy of northern North America for the five thrush species.

Homogeneity in divergence time estimates for the three 'taxon' dataset of Hermit Thrush, Swainson's Thrush, and Gray-cheeked Thrush and Veery combined yielded a ratio of variance to mean divergence times of $\Omega=0.00(95 \%$ quantiles $=0.00-2.56)$ and a value for the number of divergence times across taxon pairs of $\Psi=1.02(95 \%$ quantiles $=1.00-2.86)$, which supports a history of simultaneous divergence among these three relatively deep splits: east versus west phylogroups for Hermit and Swainson's thrushes and between the Gray-cheeked Thrush and Veery (Figs. 2 and 4).

\section{DISCUSSION}

Two primary patterns of transcontinental divergence were found among these five North American thrush species. Shallow levels of divergence were observed between eastern and western populations of the Gray-cheeked Thrush, Veery, and American Robin, whereas deeper divergences were seen in Hermit and Swainson's thrushes (Figs. 1 and 3). These five thrush species also appeared to have five significantly different coalescence events between eastern and western populations. On the other hand, the relatively deep divergences between eastern and western phylogroups within Hermit and Swainson's thrushes seemed to share a coalescence time with the split between Gray-cheeked Thrush and Veery (Fig. 2). These results indicate that despite their ecological similarity these five thrush species came to occupy northern North America in more than one way, with individual, species-level differences and two broad continental patterns. 
Occupancy across northern North America.-We hypothesized that ecologically similar thrush species would share a pattern of transcontinental divergence, and that this pattern would be similar to continental divergences in mtDNA that have been found in other vertebrate species. However, the five thrush species did not share a single pattern of divergence, and only two of the three showed the type of transcontinental mtDNA split we had predicted based on other studies (Milot, Gibbs, \& Hobson 2000, Omland et al. 2000, Arbogast \& Kenagy 2001, Kimura et al. 2002, Peters, Gretes, \& Omland 2005, Ruegg \& Smith 2002). There is nothing obvious about the individual species' ecologies that seems concordant with these results.

The Veery and American Robin had little structure between eastern and western populations (Fig. 2d and e). The Gray-cheeked Thrush had no shared haplotypes between eastern and western populations, thus indicating a somewhat deeper divergence than in the Veery and robin, but few mutations separated these populations (Fig. 2c). These three species may have spread across the continent to occupy their current ranges from single ancestral populations maintained through at least the last glacial maximum. Isolation by distance, gene flow, and extinction of a continental phylogroup may also affect the patterns observed in these three species.

Hermit and Swainson's thrushes had relatively deep divergences between eastern and western phylogroups (Fig. 2a and b). These splits did not exactly match the sampled eastern and western populations; however, this divergence is similar to patterns reported in other studies (Arbogast \& Kenagy 2001, Weir \& Schluter 2004). Previous population genetic research on Swainson's Thrushes found mtDNA sequence divergence between Pacific coastal and continental populations with a tension zone of secondary contact between them (Ruegg \& Smith 2002, Ruegg, Hijmans, \& Moritz 2006, Ruegg 2008). This indicates that eastern and western populations of Swainson's and Hermit thrushes were likely split during historic vicariant events and were isolated from one another throughout much of the Pleistocene. After the last glacial maximum ( 19,000 ybp), they expanded across the continent into their current ranges and came into secondary contact (Fig. 3). 
Because most avian species at higher latitudes are expected to have undergone postglacial population expansions, we expected to see relatively low values of $\mathrm{R}_{2}$ and Fu's $F_{s}$ indicating these expansions (Hewitt 1996). However, some populations in our study showed a signal of population stability (Table 1). This may be partly due to sampling error from small sample sizes (e.g., eastern population of the Gray-cheeked Thrush) and the relatively deep splits within species and shared haplotypes in the western populations of Hermit and Swainson's thrushes (Fig. 2a and b).

The eastern Swainson's Thrush population had a signal of recent rapid expansion, whereas the western population did not (Table 1). This is consistent with the findings of Ruegg \& Smith (2002), whose results showed expansion in continental populations of Swainson's Thrush but not in western coastal populations. This pattern has also been observed in other avian studies (Milot, Gibbs, \& Hobson 2000, Peters, Gretes, \& Omland 2005). However, at the phylogroup (rather than population) scale, our results had both eastern and western phylogroups of Swainson's Thrush showing strong signals of expansion, as did both of the Hermit Thrush phylogroups (Table 1). The eastern Swainson's Thrush and Hermit Thrush phylogroups did have lower negative Fu's $F_{s}$ statistics than the western phylogroups, supporting the possibility that the eastern phylogroups may have had greater expansion than the western ones (Table 1).

Gray-cheeked Thrush as a species had a signal of expansion (Table 1), as would be expected by a spread across northern North America from a common ancestral population after glacial recession from the last glacial maximum (Fig. 1; QEN 1997). The separation of eastern and western haplotypes (Fig. 2) may indicate a relatively short vicariant split between populations of this species during, for example, the last glacial maximum, but it might also represent isolation by distance with limited transcontinental gene flow. The American Robin and Veery had no signals of population expansion. As the southernmost breeding members of this assemblage, it is 
possible that populations of these species did not expand significantly following the last glacial maximum.

200 Patterns shared with other vertebrates. - Several transcontinentally distributed North

201 American bird and mammal taxa exhibit mitochondrial lineage breaks between the northwest

202 coast and lineages found in the rest of their North American range (Table 3). These western-

203 versus-eastern patterns of differentiation are widely considered to be the result of glacial history

204 and corresponding climatic and ecological changes over time (Pielou 1991; Arbogast \& Kenagy

205 2001, Weir \& Schluter 2004, Ruegg, Hijmans \& Moritz 2006). Although two of the east-west

206 divergences found among these studies (Table 3) may pre-date the Pleistocene (Omland et al.

207 2000, Toews \& Irwin 2008), the divergence levels that we found among thrushes (Table 2, Fig. 3)

208 are generally contemporaneous with these many Pleistocene-era divergences.

Our estimate of divergence time (TMRCA) between the eastern and western phylogroups in Swainson's Thrush is one or two orders of magnitude older than that estimated by Ruegg \& Smith (2002), who estimated the time of divergence between these two groups as 10,000 ybp. Differences in time estimates could be due to using different genes and different estimates of mutation rate. Ruegg \& Smith (2002) used the mitochondrial control region and an estimated divergence rate of $14.8 \%$ per million years, which is a much higher mutation rate than is usually assumed for passerines (Marshal \& Baker 1997, Bensch, Andersson, \& Akesson 1999, Griswold \& Baker 2002, Bulgin et al. 2003, Perez-Tris et al. 2004, Davis et al. 2006).

Divergences among thrushes.-When we compared eastern and western population divergences among these five thrush species, the divergence dates $(t)$ all occurred within the last 300,000 years (Table 2, Fig. 3). However, our analysis of these five species indicated that there was more than one and perhaps as many as five different divergence or vicariance events for the five species (Table 1, Fig. 3). It thus seems quite possible (Fig. 4) that each species had its own 
unique history of how it came to occupy a transcontinental range in northern North America, even though they inhabit similar and in some cases nearly identical northern communities.

At a deeper level, examining the relatively deep events of cladogenesis in our datasets, the eastern and western phylogroup splits within Hermit and Swainson's thrushes and the divergence between the Gray-cheeked Thrush and Veery occurred during a similar time interval (Table 2, Fig. 3). This suggests a shared divergence period within Hermit and Swainson's thrushes and between the Gray-cheeked Thrush and the Veery and that the time that a lineage has had to occupy transcontinental North America affects whether it exhibits relatively deep east-west splits. Hermit and Swainson's thrushes have existed as species much longer than the Gray-cheeked Thrush, Veery, and American Robin ( $\sim .0$ and 2.6 million ybp versus $\sim 0.4,0.4$, and 0.32 million ybp, respectively; Outlaw et al. 2003, Voelker et al. 2007). Variation in the time available to spread across the continent could influence among-species phylogeographic heterogeneity, and the corroboration here between lineage age and higher-order pattern suggests that it does influence our results.

It is now generally agreed that glacial cycling in the Pleistocene created much of the observed interspecific and sister-species level divergences in many songbird species, especially in the northern hemisphere (Klicka \& Zink 1997, Avise \& Walker 1998, Johnson \& Cicero 2004, Weir $\&$ Schluter 2004, Lovette 2005). Our results indicate that the divergence events apparent in some thrush species also probably occurred within the Pleistocene (Table 2, Fig. 3). Paleoecological data suggest that forest habitat may have been present in North America to the east and west, just south of the last glacial maximum's southern expanse, while the center of the continent was grassland and desert (Pielou 1991, Crowley 1995, QEN 1997). For forest-dependent species this could have been a significant barrier to gene flow, even among long-distance seasonal migrants, and may have caused relatively isolated breeding populations in forest refugia. When the glaciers receded, breeding ranges could expand into their current ranges (Pielou 1991, Weir \& Schluter 
2004, Ruegg, Hijmans, \& Moritz 2006). This description of the last glacial maximum and expansion into new ranges may describe recently diverged species or populations. However, older glacial cycles in the Pliocene and the early- to mid-Pleistocene may have affected populations and species in similar ways, and thus created patterns such as those seen in the deeply divergent phylogroups within Hermit and Swainson's thrushes and between the Graycheeked Thrush and Veery.

In the broader context, patterns other than east-west divergences emerged during the Pleistocene. For example, the divergence between Gray-Cheeked Thrush and Veery is largely north-south (Fig. 1), as it is also between the American Robin and its sister the Rufous-collared

212 Robin (Turdus rufitorques; Voelker et al. 2007). However, it seems that the majority of

213 divergence patterns are east-west in northern North America. In addition, at this larger scale it is

214 possible that the lack of transcontinental structure in the American Robin might be due to a rapid 215 northern expansion into a region without other Turdus species as competitors. This leaves open 216 the question, however, of why similar expansions did not occur in the Wood Thrush and Varied 217 Thrush, both of which lack congeners in North America. Thus, the role that competition might 218 play in affecting these results is not clear.

Weir \& Schluter (2004) found that many bird species complexes in boreal regions diverged into east (taiga) and west (Pacific coast) phylogroups about $1.2( \pm 0.10)$ million ybp. Because ice sheets did not form a single ice mass until the second half of the Pleistocene, it is likely that long periods of boreal fragmentation into eastern and western regions occurred during the early- to mid-Pleistocene (1.8-0.8 million ybp) when glaciers began to increase (Barendregt \& Irving 1998, Weir \& Schluter 2004). The 95\% credible interval for estimated dates of divergence (TMRCA) between phylogroups in Hermit and Swainson's thrushes and between the Graycheeked Thrush and Veery overlap this period. Contemporary gene flow between Hermit and 
Swainson's thrush phylogroups (e.g., in Hyder, Alaska) and their relative lack of phenotypic differentiation as opposed to the Gray-cheeked Thrush and Veery, suggest that these two lineages within each species did not sufficiently differentiate during previous separation to achieve reproductive isolation and full biological speciation.

219 Conclusion.-From the perspective of community genetics, these five North American

220 thrushes became widespread members of northern forests and woodlands in different ways.

221 Multiple factors, from the local, ecological level (e.g., competition), to regional, evolutionary

222 levels (e.g., climatic and glacial changes), were likely involved in producing the current

223 transcontinental ranges observed in these five ecologically similar North American thrushes. It is

224 of interest that there are species-level patterns but that two overriding patterns are also

225 evident-i.e., a lack of homogeneity at one organizational level (five separate divergence levels

226 within species is most probable) with evidence of concordance around two general patterns at

227 another, among-species level, likely related to lineage age. This suggests that the processes that

228 brought about these present continental assemblages are neither fixed, causing all species to have

229 the same historical pattern, nor completely stochastic, in that there are two general patterns of 230 divergence.

231

232 ACKNOWLEDGMENTS

233 Genetic samples were supplied by the University of Alaska Museum and the University of

234 Washington Burke Museum. Thanks to C. Barger, R. W. Dickerman, D. D. Gibson, A. B.

235 Johnson, and T. M. Braile for their assistance in field and laboratory. KW thanks Canadian

236 authorities for collecting permits. Thanks also to J. L. Peters and T. Roberts for consultation, to

237 M. J. Hickerson and N. Takebayashi for assistance and guidance on using msBayes, and to

238 Martin Paeckert and an anonymous reviewer for comments on a previous draft. 
241 Altekar G, Dwarkadas S, Huelsenbeck JP, Ronquist F. 2004. Parallel Metropolis-coupled Markov

242 chain Monte Carlo for Bayesian phylogenetic inference. Bioinformatics 20:407-415.

243 Alvarado AH. 2011. Evolutionary dynamics across a migratory divide: testing the causes and

244 consequences of divergence in hermit thrushes (Catharus guttatus). PhD thesis,

$245 \quad$ University of California Los Angeles.

246 American Ornithologist's Union (AOU). 1998. Check-list of North American Birds, 7th ed.

247 American Ornithologist's Union, Washington, D.C.

248 Andrew RL, Bernatchez L, Bonin A, Buerkle CA, Carstens BC, Emerson BC, Garant D, Giraud

249 T, Kane NC, Rogers SM, Slate J, Smith H, Sork VL, Stone GN, Vines TH, Waits L,

250 Widmer A, Rieseberg LH. 2013. A road map for molecular ecology. Molecular Ecology

$251 \quad 22: 2605-2626$.

252 Arbogast BS. 1999a. Mitochondrial DNA phylogeography of the New World flying squirrels

253 (Glaucomys): implication for Pleistocene biogeography. Journal of Mammalogy 80:142-

$254 \quad 155$.

255 Arbogast BS, Browne RA, Weigl PD. 2001. Evolutionary genetics and Pleistocene biogeography

256 of North American tree squirrels (Tamiasciurus). Journal of Mammalogy 82:302-319.

257 Arbogast BS, Kenagy GJ. 2001. Comparative phylogeography as an integrative approach to

258 historical biogeography. Journal of Biogeography 28:819-825.

259 Avise, J. C. 2000. Phylogeography: The History and Formation of Species. Harvard University

$260 \quad$ Press, Cambridge, Massachusetts.

261 Avise JC, Walker D. 1998. Pleistocene phylogeographic effects on avian populations and the

262 speciation process. Proceedings of the Royal Society of London Series B, Biological

$263 \quad$ Sciences 265:457-463. 
264 Barendregt RW, Irving E. 1998. Changes in the extent of North American ice sheets during the 265 late Cenozoic. Canadian Journal of Earth Science 35:504-509.

266 Bensch S, Andersson T, Akesson S. 1999. Morphological and molecular variation across a migratory divide in willow warblers, Phylloscopus trochilus. Evolution 53:1925-1935.

268 Bent AC. 1949. Life histories of North American thrushes, kinglets and their allies. Smithsonian 269 Institution, United States National Museum Bulletin 196.

Bulgin NL, Gibbs HL, Vickery P, Baker AJ. 2003. Ancestral polymorphisms in genetic markers obscure detection of evolutionarily distinct populations in the endangered Florida grasshopper sparrow (Ammodramus savannarum floridanus). Molecular Ecology 12:831844.

274 Carstens BC, Brunsfeld SJ, Demboski JR, Good JM, Sullivan J. 2005. Investigating the evolutionary history of the Pacific Northwest mesic forest ecosystem: hypothesis testing within a comparative phylogeographic framework. Evolution 59:1639-1652.

Clement M, Posoda D, Crandall KA. 2000. TCS: a computer program to estimate gene genealogies. Molecular Ecology 9:1657-1660.

Crowley TJ. 1995. Ice-age terrestrial carbon changes revisited. Global Biogeochemical Cycles 9:377-389.

Davis LA, Roalson EH, Cornell KL, McClanahan KD, Webster MS. 2006. Genetic divergence and migration patterns in North American passerine bird: implications for evolution and conservation. Molecular Ecology 15:2141-2152.

284 Demboski JR, Stone KD, Cook JA. 1999. Further perspectives on the Haida Gwaii glacial 285 refugium. Evolution 53:2008-2010. DNA variation in American alligators and whooping cranes. Ph.D. dissertation, University of Maryland, College Park. 
Griswold CK, Baker AJ. 2002. Time to the most recent common ancestor and divergence times of populations of common chaffinches (Fringilla coelebs) in Europe and North Africa: insights into Pleistocene refugia and current levels of migration. Evolution 56:143-153.

292 Harshman J. 1996. Phylogeny, evolutionary rates, and ducks. Ph.D. dissertation, University of 293 Chicago, Chicago Illinois.

294 Hewitt GM. 1996. Some genetic consequences of ice ages, and their role in divergence and speciation. Biological Journal of the Linnean Society 58:247-276.

Hey J, Nielsen R. 2004. Multilocus methods for estimating population sizes, migration rates and

Hickerson MJ, Stahl EA, Lessios HA. 2006. Test for simultaneous divergence using approximate Bayesian computation. Evolution 60:2435-2453.

Ho SYW, Lanfear R, Bromham L, Phillips MJ, Soubrier J, Rodrigo AG, Cooper A. 2011. Time-

312 Huelsenbeck JP, Ronquist F. 2001. MRBAYES: Bayesian inferences of phylogenetic trees. 
314 Johnson NK, Cicero C. 2004. New mitochondrial DNA data affirm the importance of Pleistocene 315 speciation in North American birds. Evolution 58:1122-1130.

316 Johnson MTJ, Stinchcombe JR. 2007. An emerging synthesis between community ecology and 317 evolutionary biology. Trends in Ecology and Evolution 22:250-257.

318 Jones PW, Donovan TM. 1996. Hermit Thrush (Catharus guttatus). In The Birds of North 319 America Online, no. 261(A. Poole, Ed.). Ithaca: Cornell Lab or Ornithology; Retrieved 320 from The Birds of North America Online: http://bna.birds.cornell.edu/bna/species/261.

321 Kimura M, Clegg SM, Lovette IJ, Holder DJ, Girman DJ, Mila B, Wade P, Smith TB. 2002. Phylogeographical approaches to assessing demographic connectivity between breeding

Klicka J, Spellman GM, Winker K, Chua V, Smith BT. 2011. A phylogeographic and population genetic analysis of a widespread, sedentary North American bird: The Hairy Woodpecker (Picoides villosus). Auk 128:346-362.

Klicka J, Voelker G, Spellman GM. 2004. A molecular phylogenetic analysis of the "true thrushes" (Aves: Turdinae). Molecular Phylogenetics and Evolution 34:486-500.

330 Klicka J, Zink RM. 1997. The importance of recent ice ages in speciation: A failed paradigm. Science 277:1666-1669.

332 Kocher TD, Thomas WK, Meyer A, Edwards SV, Pääbo S, Villablanca FX, Wilson AC. 1989. Dynamics of mitochondrial DNA evolution in animals: amplification and sequencing with conserved primers. Proceedings of the National Academy of Sciences USA 86:6196-6200.

335 Lait LA, Burg TM. 2013. When east meets west: population structure of a high-latitude resident 336 species, the boreal chickadee (Poecile hudsonicus). Heredity 111:321-329.

Lovette IJ. 2004. Mitochondrial dating and mixed support for the "2\% rule" in birds. Auk 121:16. 
Lovette IJ. 2005. Glacial cycles and the tempo of avian speciation. Trends in Ecology and Evolution 20:57-59.

Lovette IJ, Hochachka WM. 2006. Simultaneous effects of phylogenetic niche conservatism and competition on avian community structure. Ecology 87:S14-S28.

Lowther PE, Rimmer CC, Kessel B, Johnson SL, Ellison WG. 2001. Gray-cheeked Thrush (Catharus minimus). In The Birds of North America Online, no. 591 (A. Poole, Ed.). Ithaca: Cornell Lab of Ornithology; Retrieved from The Birds of North America Online: http://bna.birds.cornell.edu/bna/species/591.

Mack DE, Yong W. 2000. Swainson's Thrush (Catharus ustulatus). In The Birds of North American Online, no. 540 (A. Poole, Ed.). Ithaca: Cornell Lab of Ornithology; Retrieved from The Birds of North America Online: http://bna.birds.cornell.edu/bna/species/540.

Manthey JD, Klicka J, Spellman GM. 2011. Cryptic diversity in a widespread North American songbird: Phylogeography of the Brown Creeper (Certhia americana). Molecular Phylogenetics and Evolution 58:502-512.

Marshall HD, Baker AJ. 1997. Structural conservation and variation in the mitochondrial control region of fringilline finches (Fringilla spp.) and greenfinch (Carduelis chloris). Molecular Biology and Evolution 14:173-184.

Maskoff W. 2005. Veery (Catharus fuscescens). In The Birds of North America Online, no. 142 (A. Poole, Ed.). Ithaca: Cornell Lab of Ornithology; Retrieved from The Birds of North America Online: http://bna.birds.cornell.edu/bna/species/142.

Milá B, Smith TB, Wayne RK. 2007. Speciation and rapid phenotypic differentiation in the yellow-rumped warbler Dendroica coronate complex. Molecular Ecology 16:159-173.

Milot E, Gibbs HL, Hobson KA. 2000. Phylogeography and genetic structure of northern populations of the yellow warbler (Dendroica petechia). Molecular Ecology 9:667-681. 
Moore WW, DeFilippis VR. 1997. The window of taxonomic resolution for phylogenies based on mitochondrial cytochrome $b$. Pages 84-115 in Avian Molecular Evolution and Systematics (D. P. Mindell, Ed.). Academic Press, San Diego, California.

Omland KE, Tarr CL, Boarman WI, Marzluff JM, Fleisher RC. 2000. Cryptic genetic variation and paraphyly in ravens. Proceedings of the Royal Society of London, Series B, Biological Sciences 267:2475-2482.

Outlaw DC, Voelker G, Mila B, Girman DJ. 2003. Evolution of long-distance migration in and historical biogeography of Catharus thrushes: a molecular phylogenetic approach. Auk 120:299-310.

Pereira SL, Baker AJ. 2006. A Mitogenomic timescale for birds detects variable phylogenetic rates of molecular evolution and refutes the standard molecular clock. Molecular Biology and Evolution 23:1731-1740.

Perez-Tris J, Bensch S, Carbonell R, Helbig AJ, Telleria JL. 2004. Historical diversification of migration patterns in a passerine bird. Evolution 58:1819-1832.

Peters JL, Gretes W, Omland KE. 2005. Late Pleistocene divergence between eastern and western populations of wood ducks (Aix sponsa) inferred by the 'isolation with migration' coalescent method. Molecular Ecology 14:3407-3418.

Peters JL, Zhuravlev Y, Fefelov I, Logie A, Omland KE. 2007. Nuclear loci and coalescent methods support ancient hybridization as cause of mitochondrial paraphyly between Gadwall and Falcated Duck (Anas spp.). Evolution 61:1992-2006.

Phillips AR. 1991. The Known Birds of North and Middle America, Part II. Published by the author, Denver, Colorado.

Pielou EC. 1991. After the Ice Age: the Return of Life to Glaciated North America. University of Chicago Press, Illinois. 
Posada D, Buckley TR. 2004. Model selection and model averaging in phylogenetics: advantages of Akaike Information Criterion and Bayesian approaches over likelihood ratio tests. Systematic Biology 53:793-808.

Posada D, Crandall KA. 1998. Modeltest: Testing the model of DNA substitution. Bioinformatics $14: 817-818$.

337 Quaternary Environments Network (QEN). 1997. Review and atlas of palaeovegetation:

338 preliminary land ecosystem maps of the world since the last glacial maximum (J. M.

339 Adams and H. Faure Eds.). Oak Ridge National Laboratory, TN, USA. Available from:

$340 \quad$ http://www.esd.ornl.gov/projects/qen/adams1.html.

341 Richman AD, Price T. 1992. Evolution of ecological differences in the Old World leaf warblers.

$342 \quad$ Nature 355:817-821.

343 Ricklefs RE. 1987. Community diversity: Relative roles of local and regional processes. Science $344 \quad 235: 167-171$.

345 Ricklefs RE. 2007. History and diversity: Explorations at the intersection of ecology and $346 \quad$ evolution. American Naturalist 170:S56-S70.

347 Rimmer CC, Mcfarland KP, Ellison WG, Goetz JE. 2001. Bicknell's Thrush (Catharus bicknelli).

348 In The Birds of North America Online, no. 592 (A. Poole, Ed.). Ithaca: Cornell Lab of

349 Ornithology; Retrieved from The Birds of North America Online:

350 http://bna.birds.cornell.edu/bna/species/592.

351 Romis-Onsins SE, Rozas J. 2002. Statistical properties of neutrality tests against population 352 growth. Molecular Biology and Evolution 19:2092-2100.

353 Ronquist F, Huelsenbeck JP. 2003. MRBAYES 3: Bayesian phylogenetic inference under mixed 354 models. Bioinformatics 19:1572-1574.

355 Rozas J, Sanchez-DelBarrio JC, Messeguer X, Rozas R. 2003. DnaSP, DNA polymorphism 356 analyses by the coalescent and other methods. Bioinformatics 19:2496-2497. 
357 Ruegg KC. 2008. Genetic, morphological, and ecological characterization of a hybrid zone that 358 spans a migratory divide. Evolution 62:452-466.

359 Ruegg KC, Hijmans RJ, Moritz C. 2006. Climate change and the origin of migratory pathways in 360 the Swainson's Thrush (Catharus ustulatus). Journal of Biogeography 33:1172-1182.

361 Ruegg KC, Smith TB. 2002. Not as the crow flies: A historical explanation for circuitous 362

Swofford DL. 2001. PAUP*: phylogenetic analysis using parsimony (* and other methods), ver.

Toews DPL, Irwin DE. 2008. Cryptic speciation in a Holarctic passerine revealed by genetic and bioacoustic analyses. Molecular Ecology 17:2691-2705.

378 van Els P, Cicero C, Klicka J. 2012. High latitudes and high genetic diversity: Phylogeography of a widespread boreal bird, the gray jay (Perisoreus Canadensis). Molecular Phylogenetics and Evolution 63:456-465. 
381 Voelker G, Rohwer S, Bowie RCK, Outlaw DC. 2007. Molecular systematics of a speciose, 382 cosmopolitan songbird genus: Defining the limits of, and relationships among, the Turdus 383 thrushes. Molecular Phylogenetics and Evolution 42:422-434.

384 Voelker G, Rohwer S, Outlaw DC, Bowie RCK. 2009. Repeated trans-Atlantic dispersal

385 catalysed a global songbird radiation. Global Ecology and Biogeography 18:41-49.

386 Voelker G, Bowie RCK, Klicka J. 2013. Gene trees, species trees and Earth history combine to 387 shed light on the evolution of migration in a model avian system. Molecular Ecology $388 \quad 22: 3333-3344$.

389 Webb CO. 2000. Exploring the phylogenetic structure of ecological communities: an example $390 \quad$ from rain forest trees. American Naturalist 156:145-155.

391 Webb CO, Ackerly DD, McPeek MA, Donoghue MJ. 2002. Phylogenies and community ecology. $392 \quad$ Annual Reviews in Ecology and Systematics 33:475-505.

393 Weir JT, Schluter D. 2004. Ice sheets promote speciation in boreal birds. Proceedings of the Royal Society of London. Series B, Biological Sciences 271:1881-1887.

395 Weir JT, Schluter D. 2008. Calibrating the avian molecular clock. Molecular Ecology 17:23213962328.

397 Winker K, Pruett CL. 2006. Seasonal migration, speciation, and morphological convergence in 398 the genus Catharus (Turdidae). Auk 123:1052-1068.

399 Wooding S, Ward R. 1997. Phylogeography and Pleistocene evolution in the North American $400 \quad$ black bear. Molecular Biology and Evolution 14:1096-1105.

401 Zink RM. 1996. Comparative phylogeography of North American birds. Evolution 50:308-31 


\section{Table 1 (on next page)}

Table of genetic diversity and population size analyses

Measures of genetic diversity and historic population size analyses calculated in DnaSP v.4.20.2 (Rozas et al. 2003) for each species total, eastern and western populations, and eastern and western phylogroups in the two species with deep divergences. Measures of diversity are: $n=$ sample number, $H=$ number of haplotypes, $S=$ segregating sites, $h=$ haplotype diversity, and $\pi$ (per site) $=$ nucleotide diversity. R2 and Fu's Fs were used to measure historical population changes. 1,000 coalescent simulations were used to determine the probability of our results under a model of constant population size. Significant results are shown in bold $(P<0.05)$. 
TABLE 1. Measures of genetic diversity and historic population size analyses calculated in DnaSP v.4.20.2 (Rozas et al. 2003) for each species total, eastern and western populations, and eastern and western phylogroups in the two species with deep divergences. Measures of diversityare: $n=$ sample number, $H=$ number of haplotypes, $S=$ segregating sites, $h=$ haplotype diversity, and $\pi$ (per site $)=$ nucleotide diversity. $\mathrm{R}_{2}$ and Fu's $F_{s}$ were used to measure historical population changes. 1,000 coalescent simulations were used $\sum$

to determine the probability of our results under a model of constant population size. Significant results are shown in bold $(P<0.05)$.

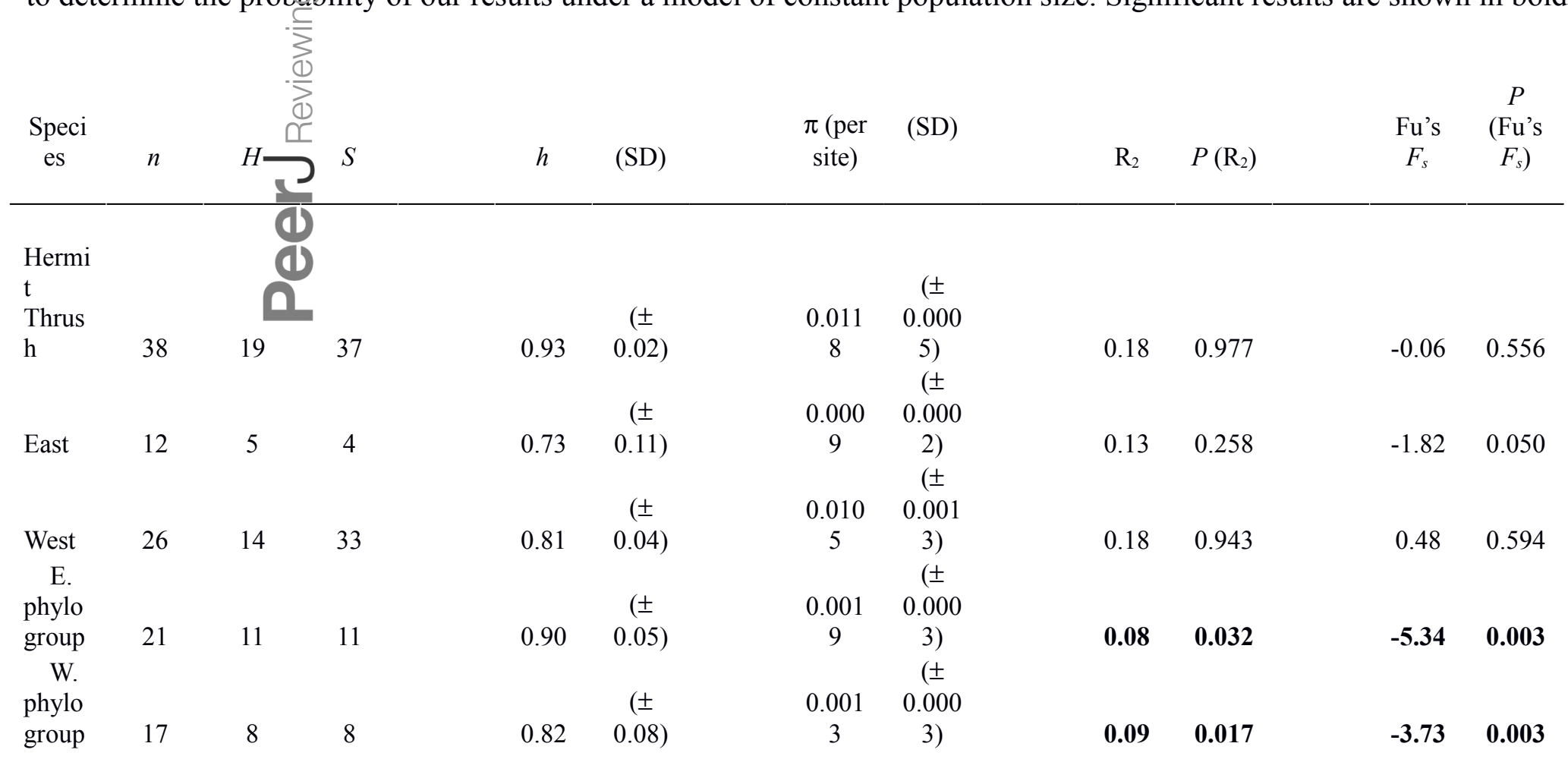




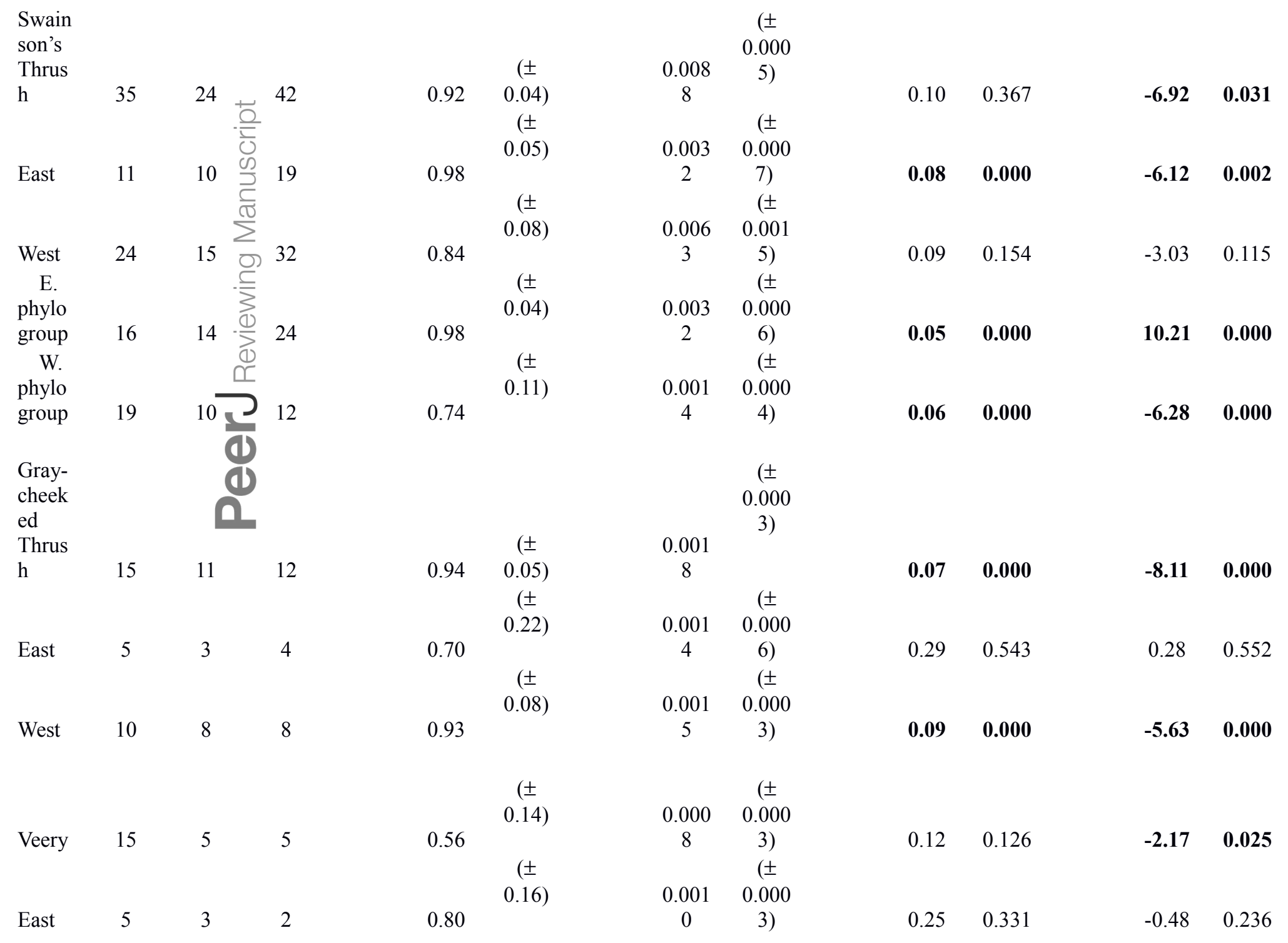




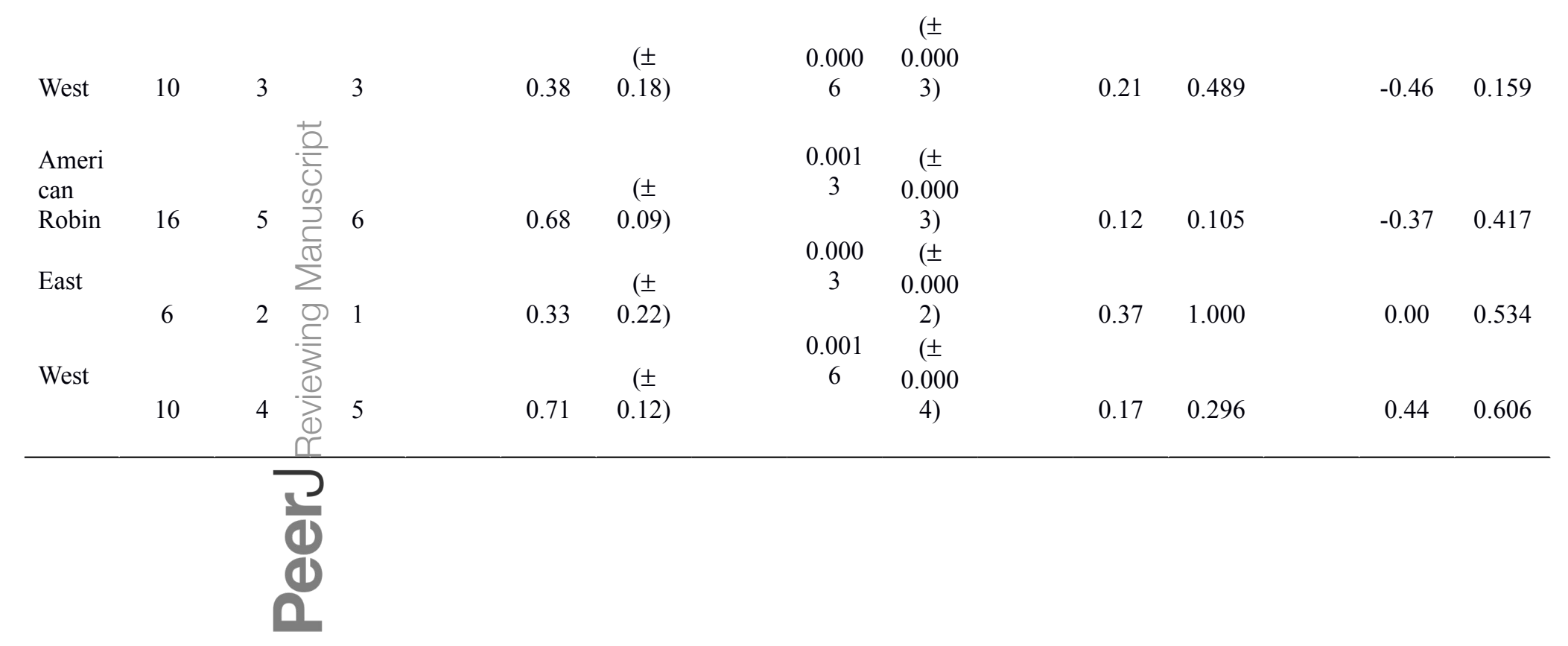




\section{Table 2 (on next page)}

IM values and divergence times

IM values and divergence time converted to years for $t$ and TMRCA. Top rows are smoothed IM values and $95 \%$ credible intervals scaled to the neutral mutation rate of divergence time $(t)$ between eastern and western samples in each species and the time to most recent common ancestor (TMRCA; divergence for clades). Bottom rows are IM values converted to time in years $(\mathrm{T})$ assuming a generation time of one year and $2 \%$ sequence divergence per million years where the mutation rate $(\mu)$ is $1 \times 10-8$ substitutions/site/lineage/year and $\mathrm{T}=\mathrm{L}$ $t / \mu$, where $\mathrm{L}=$ the length of the sequence in base pairs. Numbers in bold represent the biologically important divergence measure for each species in describing continent-wide divergence. 
TABLE 2. IM values and divergence time converted to years for $t$ and TMRCA. Top rows are smoothed IM values and $95 \%$ credible intervals scaled to the neutral mutation rate of divergence time $(t)$ between eastern and western samples in each species and the time to most recent common ancestor (TMRCA; divergence for clades). Bottom rows are IM values converted to time in years (T) assuming a generation time of one year and $2 \%$ sequence divergence per million years where the mutation rate $(\mu)$ is $1 \times 10^{-8}$ substitutions/site/lineage/year and $\mathrm{T}=\mathrm{L} t / \mu$, where $\mathrm{L}=$ the length of the sequence in base pairs. Numbers in bold represent the biologically important divergence measure for each species in describing continent-wide divergence.

\begin{tabular}{|c|c|c|c|c|}
\hline Species & $t$ & $\begin{array}{c}95 \% \\
\text { low - high }\end{array}$ & TMRCA & $\begin{array}{c}95 \% \\
\text { low - high }\end{array}$ \\
\hline Hermit Thrush & $\begin{array}{c}0.65 \\
56,430\end{array}$ & $\begin{array}{c}0.44-\text { na* }^{*} \\
38,373-\text { na* }^{*}\end{array}$ & $\begin{array}{c}11.79 \\
1,031,601\end{array}$ & $\begin{array}{c}8.26-17.12 \\
722,240-1,498,023\end{array}$ \\
\hline Swainson's Thrush & $\begin{array}{c}0.72 \\
65,841\end{array}$ & $\begin{array}{c}0.39-1.67 \\
35,384-152,733\end{array}$ & $\begin{array}{c}8.23 \\
752,002\end{array}$ & $\begin{array}{c}5.44-12.50 \\
496,810-1,142,934\end{array}$ \\
\hline Gray-cheeked Thrush & $\begin{array}{c}0.74 \\
65,092\end{array}$ & $\begin{array}{c}0.31-2.48 \\
27,017-216,833\end{array}$ & $\begin{array}{c}1.37 \\
119,528\end{array}$ & $\begin{array}{c}0.79-3.12 \\
68,714-273,123\end{array}$ \\
\hline Veery & $\begin{array}{c}0.34 \\
32,651\end{array}$ & $\begin{array}{c}0.08-2.30 \\
7,291-220,450\end{array}$ & $\begin{array}{c}0.73 \\
69,971\end{array}$ & $\begin{array}{c}0.34-2.51 \\
32,536-240,191\end{array}$ \\
\hline American Robin & $\begin{array}{c}0.19 \\
16,807\end{array}$ & $\begin{array}{c}0.09-3.30 \\
8,180-\text { na* }^{*}\end{array}$ & $\begin{array}{c}1.31 \\
114,304\end{array}$ & $\begin{array}{c}0.62-3.25 \\
54,514-284,296\end{array}$ \\
\hline $\begin{array}{l}\text { Gray-cheeked Thrush } \\
\text { and Veery }\end{array}$ & na & na & $\begin{array}{c}\mathbf{5 . 9 9} \\
\mathbf{5 7 2 , 9 6 7}\end{array}$ & $\begin{array}{c}5.11-9.66 \\
489,234-924,641\end{array}$ \\
\hline
\end{tabular}




\section{Table 3 (on next page)}

Other taxa with mtDNA breaks

Other transcontinentally distributed vertebrates with mtDNA lineage breaks between the northwest coast and lineages found in the rest of their North American range. 
Table 3. Other transcontinentally distributed vertebrates with mtDNA lineage breaks between the northwest coast and lineages found in the rest of their North American range.

\begin{tabular}{|c|c|c|c|c|}
\hline Species- & mtDNA marker & $\begin{array}{c}\text { Divergenc } \\
\mathrm{e} \\
\% \\
\text { divergenc } \\
\mathrm{e} \\
\end{array}$ & estimate & Source \\
\hline Birds & & & & \\
\hline Wood Duck (Aix sponsa) $\quad \frac{\frac{\sigma}{\vec{\sigma}}}{\sum}$ & control region & -- & $\begin{array}{l}124,000- \\
10,000 \\
925,000-\end{array}$ & Peters, Gretes, \& Omland 2005 \\
\hline Hairy Woodpecker (Picoides vilïpsus) & NADH dehydrogenase subunit 2 & $\sim 1.5 \%$ & $\begin{array}{c}470,000 \\
5,520,000\end{array}$ & Klicka et al. 2011 \\
\hline Gray Jay (Perisoreus canaden & NADH dehydrogenase subunit 2 & $4.6-5.1 \%$ & 890,000 & van Els, Cicero, \& Klicka 2012 \\
\hline Common Raven (Corvus corax & cytochrome $b$, control region & $4.0-5.0 \%$ & $\begin{array}{l}\sim 2,000,000 \\
133,300-\end{array}$ & Omland et al. 2000 \\
\hline Boreal Chickadee (Poecile hugsonicus) & control region, ATPase & -- & $\begin{array}{c}26,700 \\
1,600,000-\end{array}$ & Lait \& Burg 2013 \\
\hline White-breasted Nuthatch (Sit ${ }^{2}$ carolinensis) & NADH dehydrogenase subunit 2 & $3.6-4.7 \%$ & 630,000 & Spellman \& Klicka 2007 \\
\hline $\begin{array}{l}\text { Brown Creeper (Certhia ame cana) } \\
\text { Winter \& Pacific wrens (Troc dytes hiemalis \& }\end{array}$ & NADH dehydrogenase subunit 2 & $1.5-3.0 \%$ & $2,500,000$ & Manthey, Klicka, \& Spellman 2011 \\
\hline pacificus) & NADH dehydrogenase subunit 2 & $\begin{array}{l}6.24 \% \\
0.13-\end{array}$ & $4,300,000$ & Toews \& Irwin 2008 \\
\hline Yellow-rumped Warbler (Setophaga coronata) & control region, ATPase $6 \& 8$ & $0.15 \%$ & $\begin{array}{l}12,000-10,000 \\
100,000-\end{array}$ & Milá, Smith, \& Wayne 2007 \\
\hline Yellow Warbler (Setophaga petechia) & control region & -- & 18,500 & Milot, Gibbs, \& Hobson 2000 \\
\hline Wilson's Warbler (Cardellina pusilla) & $\begin{array}{l}\text { control region } \\
\text { cytochrome } b, \mathrm{NADH}\end{array}$ & $1 . \overline{--}$ & $62,500-33,654$ & Kimura et al. 2002 \\
\hline Fox Sparrow (Passerella iliaca) & dehydrogenase subunit 2 & $1.91 \%$ & 770,000 & Weir \& Schluter 2004 \\
\hline \multicolumn{5}{|l|}{ Mammals } \\
\hline shrews (Sorex bairdi and S. monticolus) & cytochrome $b$ & $4.7-5.7 \%$ & $\begin{array}{c}-- \\
1,200,000-\end{array}$ & Demboski, Stone, \& Cook 1999 \\
\hline $\begin{array}{l}\text { northern flying squirrel (Glaucomys sabrinus) } \\
\text { tree squirrels (Tamiasciurus douglasii+mearnsi and }\end{array}$ & cytochrome $b$ & $4.3 \%$ & $\begin{array}{l}770,000 \\
240,000-\end{array}$ & Arbogast 1999a \\
\hline T. hudsonicus) & cytochrome $b$ & $1.0-2.4 \%$ & 80,000 & Arbogast, Brown, \& Weigl 2001 \\
\hline red-backed voles (Myodes gapperi) & cytochrome $b$ & $\begin{array}{c}3.3 \% \\
5 \%, 3.1-\end{array}$ & -- & $\begin{array}{l}\text { Runck \& Cook } 2005 \\
\text { Wooding \& Ward 1997, Stone \& }\end{array}$ \\
\hline black bear (Ursus americanus) & control region, cytochrome $b$ & $3.6 \%$ & $1,800,000$ & Cook 2000 \\
\hline American pine marten (Martes americana) & cytochrome $b$ & $2.5-2.8 \%$ & -- & Demboski, Stone, \& Cook 1999 \\
\hline
\end{tabular}




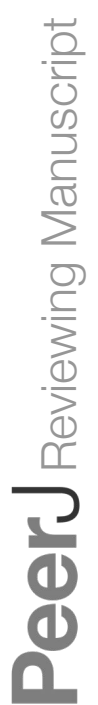




\section{Figure 1}

Figure 1. Thrush distribution maps.

Maps of species breeding ranges with sample locations shown: Hermit Thrush (a), Swainson's Thrush (b), Gray-cheeked Thrush (c), Veery (d), and American Robin (e). Maps are based on the Birds of North America Online http://bna.birds.cornell.edu/bna and AOU (1998). Black circles are proportional in size to the number of individuals sampled from each location. Locations are eastern: Nova Scotia (NvSc) and Newfoundland (Newf); and western: Interior Alaska (AK), Southeast Alaska (SE AK), Hyder, Alaska (Hyder), Queen Charlotte Islands $(\mathrm{QCl})$, and Washington state (WA). 

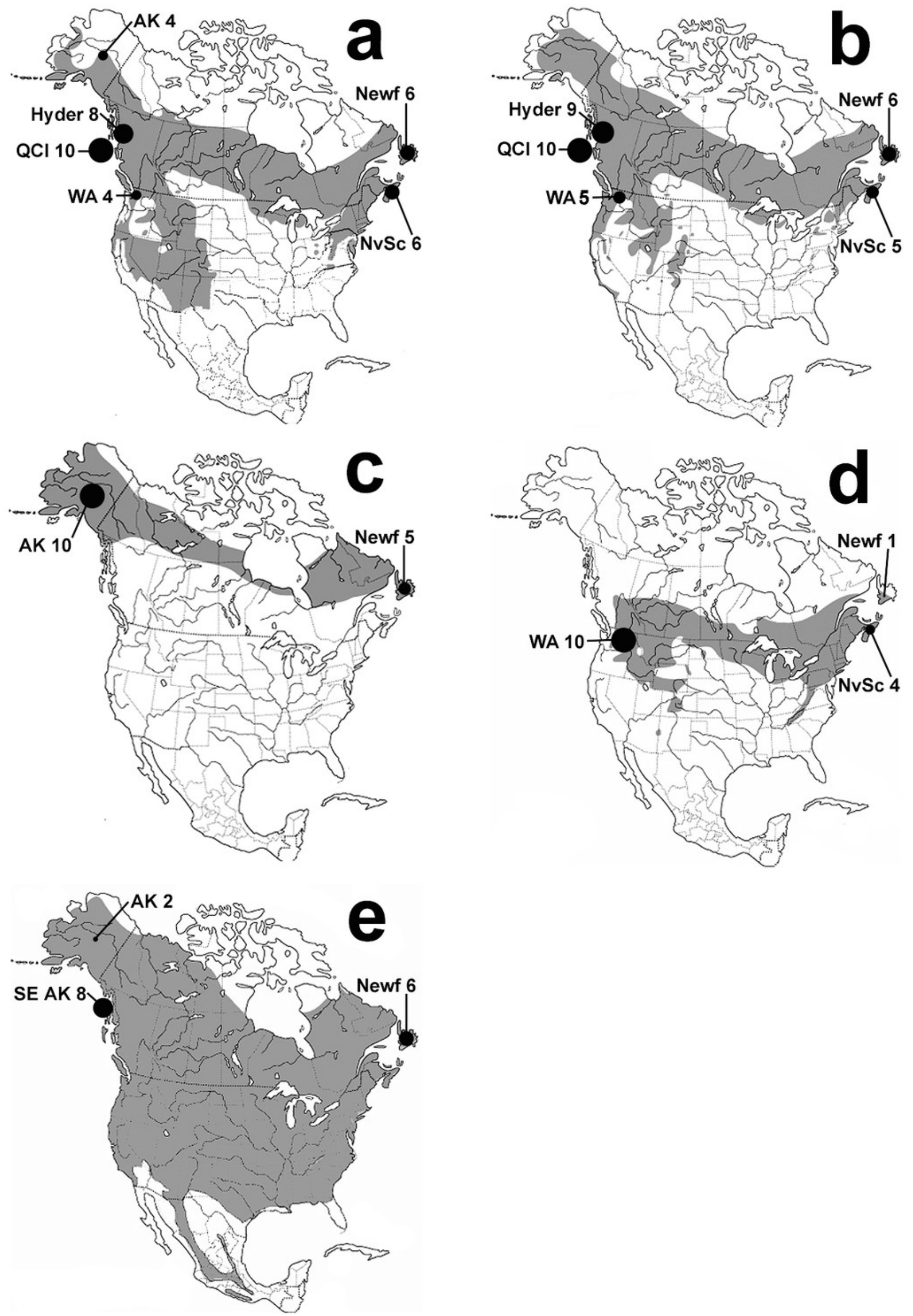


\section{Figure 2}

Figure 2. Haplotype networks and trees.

Statistical parsimony networks showing haplotype relationships and the number of individuals with each haplotype. Shading indicates general sampling areas in North America; black = eastern, white $=$ western, and gray $=$ Hyder, Alaska. The size of each circle is proportional to the number of individuals with each haplotype. The length of connecting lines is proportional to the number of base pair differences between haplotypes. The phylograms on the right are sized proportionally to each other. Phylogeographically important nodes with Bayesian posterior probabilities of 1.0 are shown with an asterisk. Inset phylogram (f) shows the Graycheeked Thrush (top clade) and Veery (bottom clade) combined. 


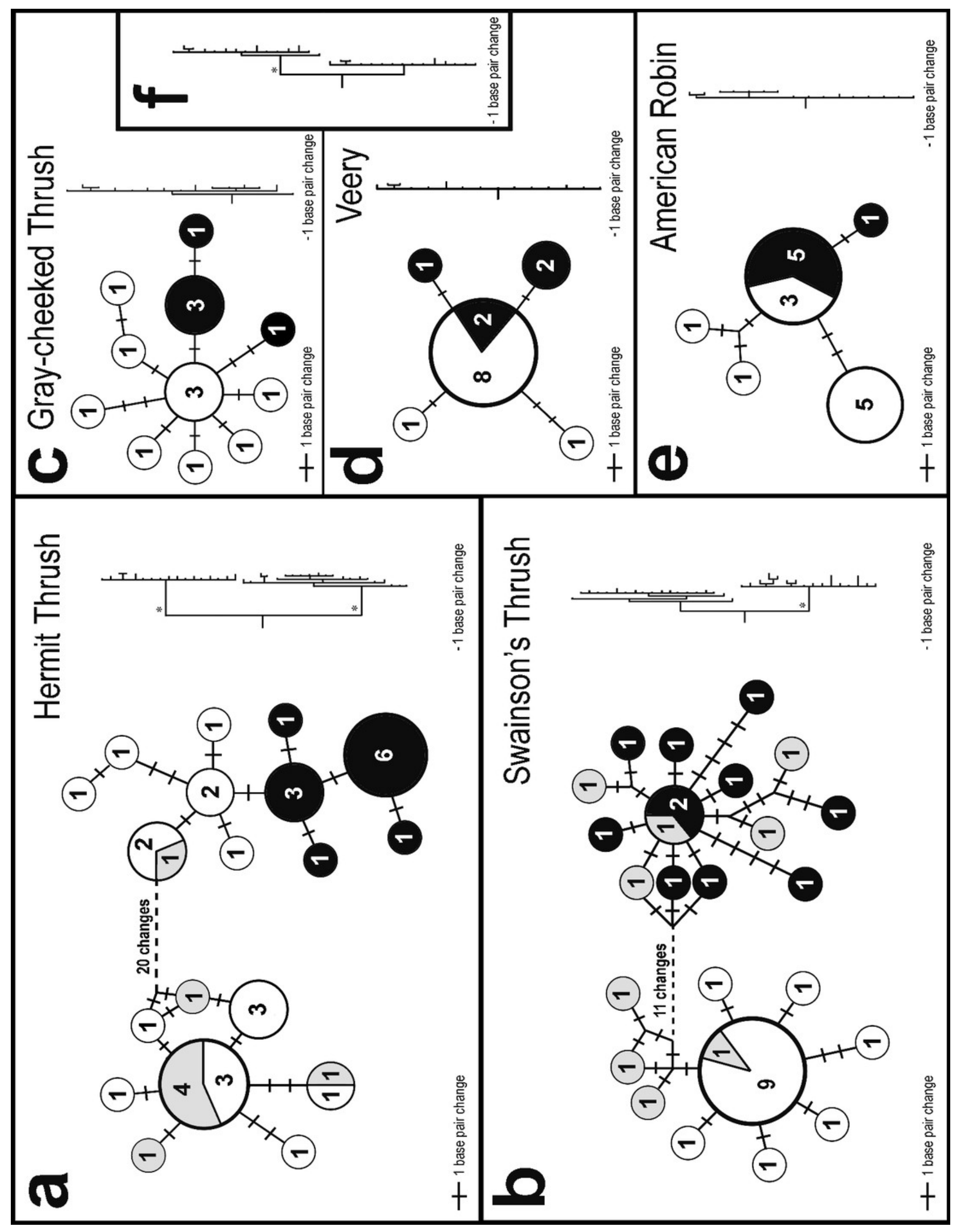




\section{Figure 3}

Figure 3. Divergence time estimates in graphic form

Divergence time in years before present converted from smoothed IM values of divergence times with 95\% credible intervals for $\mathrm{t}$ (white bars) and TMRCA (gray bars), assuming a oneyear generation time and $2 \%$ sequence divergence per million years for cyt $b$ in passerines. Along the bottom is a geological time scale showing different segments of the Pleistocene and the Wisconsin glacial period (W). The last glacial maximum ( 18,000 ybp) is shown with a thick line within the late Wisconsin. An asterisk indicates that the upper $95 \%$ credible interval value was used from TMRCA (see methods). 


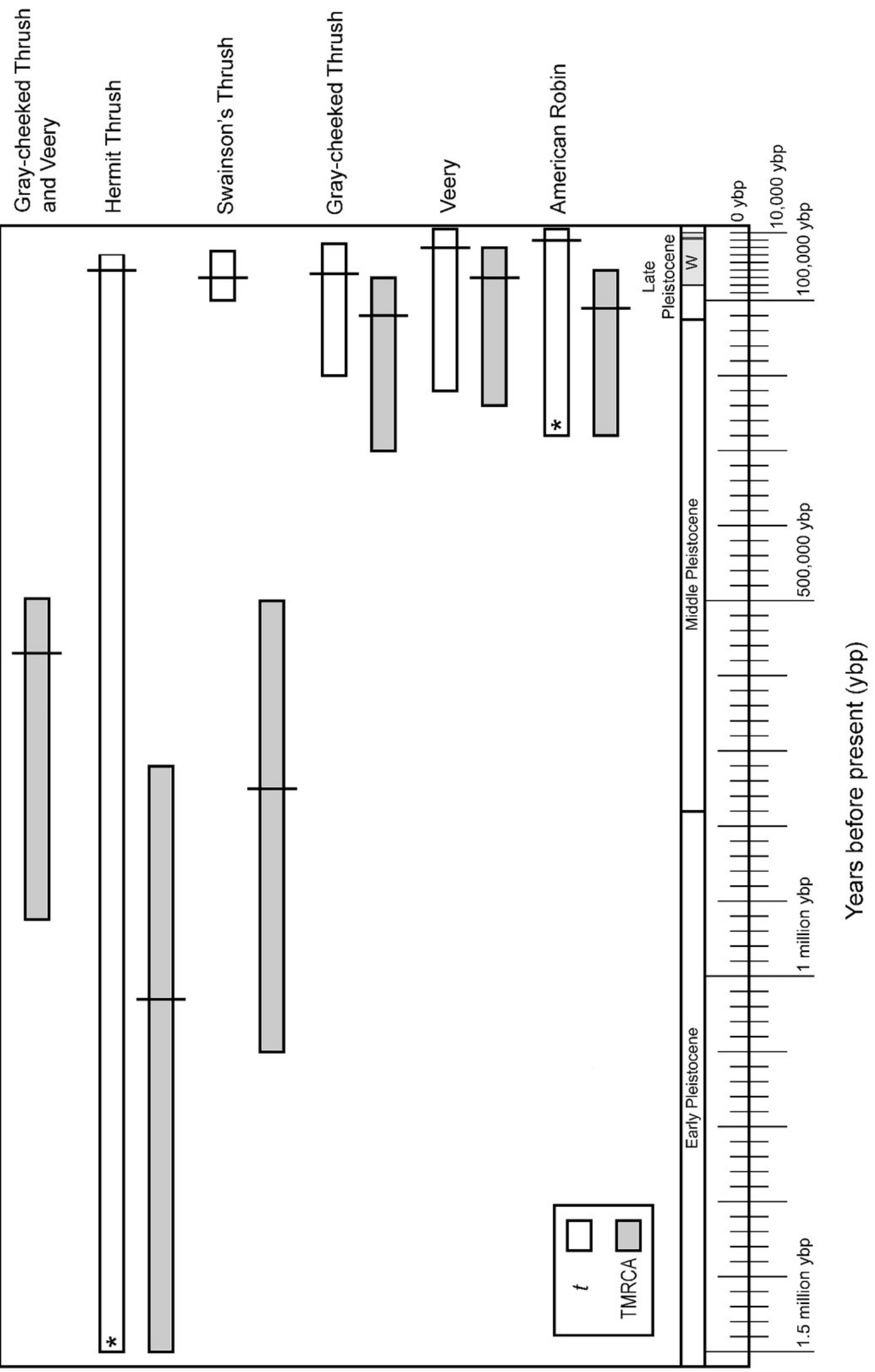




\section{Figure 4}

Figure 4. msBayes results.

msBayes posterior probability graphs of $\Psi$ (Psi) for the five-taxon dataset (all five thrush species east-west populations) and the three 'taxon' dataset (Hermit Thrush and Swainson's Thrush phylogroups, and Gray-cheeked Thrushes and Veeries combined). 
Five taxa
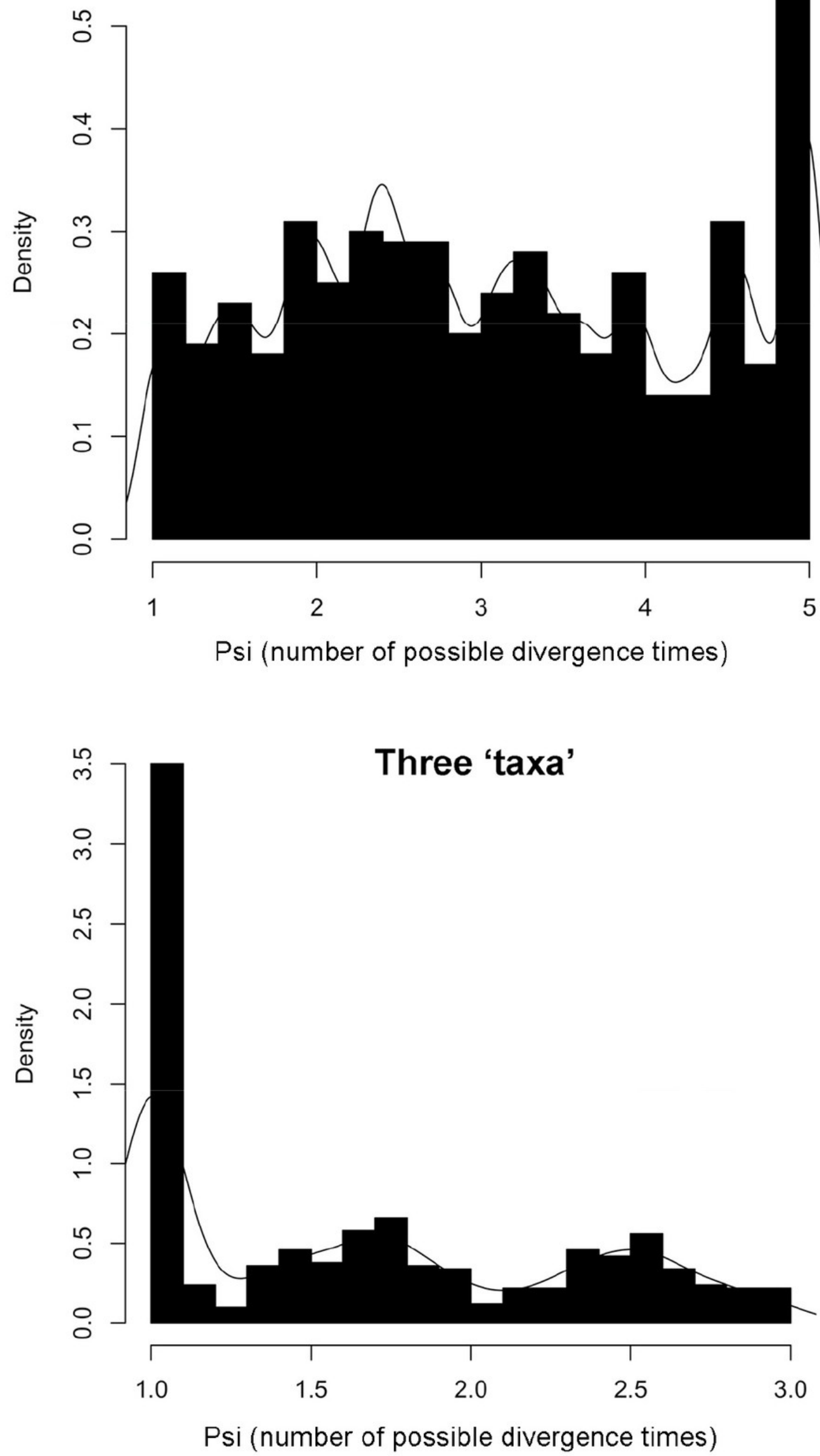


\section{Table 4 (on next page)}

\section{Appendices}

Voucher numbers and GenBank accessions 


\section{APPENDIX 1}

Voucher numbers and GenBank accessions.

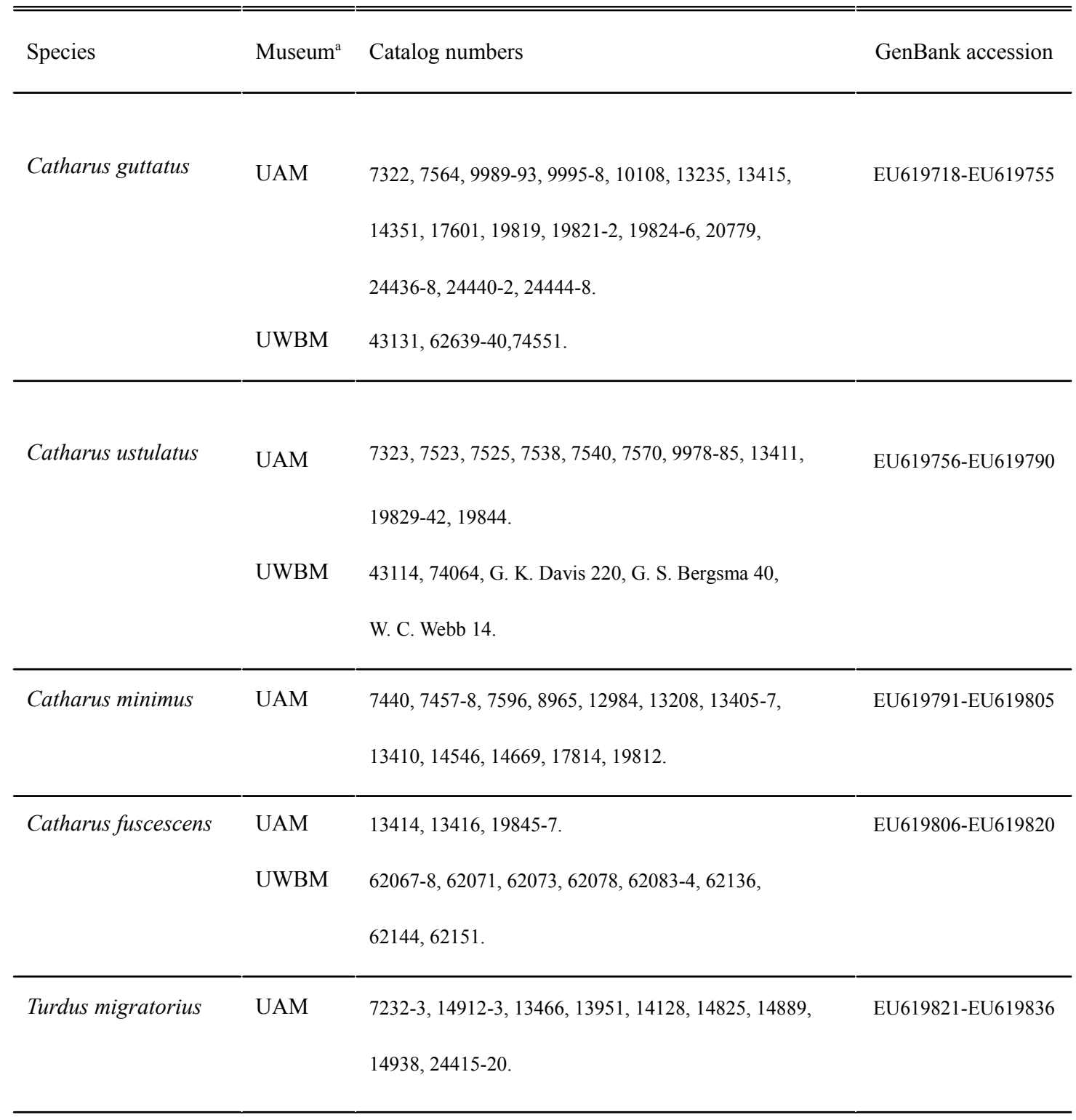

${ }^{a}$ University of Alaska Museum; University of Washington Burke Museum. 


\section{APPENDIX 2}

GenBank accessions for Outgroup taxa.

\begin{tabular}{|c|c|c|}
\hline Species & Outgroup & GenBank accession \\
\hline Catharus guttatus & $\begin{array}{l}\text { Catharus gracilirostris } \\
\text { Catharus occidentalis }\end{array}$ & $\begin{array}{l}\text { AY049497 } \\
\text { AY049506 }\end{array}$ \\
\hline Catharus ustulatus & $\begin{array}{l}\text { Catharus gracilirostris } \\
\text { Catharus occidentalis }\end{array}$ & $\begin{array}{l}\text { AY049497 } \\
\text { AY049506 }\end{array}$ \\
\hline Catharus minimus & $\begin{array}{l}\text { Catharus bicknelli } \\
\text { Catharus fuscescens }\end{array}$ & $\begin{array}{l}\text { AY049490 } \\
\text { AY049495 }\end{array}$ \\
\hline Catharus fuscescens & $\begin{array}{l}\text { Catharus bicknelli } \\
\text { Catharus minimus }\end{array}$ & $\begin{array}{l}\text { AY049490 } \\
\text { AY049503 }\end{array}$ \\
\hline Turdus migratorius & $\begin{array}{l}\text { Turdus libonyanus } \\
\text { Turdus obscurus }\end{array}$ & $\begin{array}{l}\text { AY752389 } \\
\text { AY049484 }\end{array}$ \\
\hline C. minimus \& C. fuscescens & $\begin{array}{l}\text { Catharus frantzii } \\
\text { Catharus occidentalis }\end{array}$ & $\begin{array}{l}\text { AY049493 } \\
\text { AY049506 }\end{array}$ \\
\hline
\end{tabular}

